\title{
Performance of novel type three dimensionally deformed steel fibres for concrete
}

PÉTER KEREKES - BSc (CE) student, BME Faculty of Civil Engineering • wubxwub@gmail.com Adorján BOROSNYÓI - Assoc. Prof., BME, Dept. of Construction Materials and Engineering Geology - borosnyoi.adorjan@epito.bme.hu

Érkezett: 2014. 10. 28. - Received: 28. 10. 2014. - http://dx.doi.org/10.14382/epitoanyag-jsbcm.2014.19

\section{Abstract}

Preliminary results of a two years long research and development project is introduced in this paper. One novel type of 2D deformed steel fibre (with the product name of PetiX) and four different types of 3D deformed steel fibres (PetiX V45; PetiX V90; PetiX S45; PetiX S60) were designed, manufactured and tested under laboratory conditions. The laboratory tests showed promising results. Superior performance of certain types of 3D deformed steel fibres was observed. Considerable improvement of the bond performance of steel fibres was realized in concrete and increased flexural toughness of SFRC prismatic specimens tested in flexure was demonstrated.

Keywords: concrete, steel fibre, 3D geometry, bond, flexural strength, toughness
Péter Kerekes Civil engineer (BSc) student at Budapest University of Technology and Economics (BME), Faculty of Civil Engineering. Main fields of interest: development and performance of steel fibres for concrete.

Adorján Borosnyói Civil engineer (MSc), PhD, Associate Professor at BME Dept. of Construction Materials and Engineering Geology. Main fields of interest: cracking and deflection of reinforced concrete, application of non-metallic (FRP) reinforcements for concrete structures, bond in concrete, nondestructive testing of concrete, supplementary cementing materials for high performance concretes, concrete technology. Member of the fib Task Group 4.1 „Serviceability Models", corresponding member of RILEM Technical Committee 249-ISC „Non destructive in situ strength assessment of concrete" and Chairman of the SZTE Concrete Division.

\section{Introduction}

The use of Steel Fibre Reinforced Concrete (SFRC) has been greatly increased in the past few decades in civil engineering [1-6]. SFRC is mostly used for industrial floors but it can provide a good solution for shear walls and prefabricated elements as well. Advantages of SFRC are the less labour work, the reduction of brittleness and the increase of toughness and shear resistance of concrete.

Most important performance parameter of steel fibres made of cold drawn steel wires is the surface geometry, therefore, several different types of steel fibres have been developed during the last decades. Hooked-end, undulated, crimped, twisted, end-anchoring, flat-end and several combined geometries are commercially available for concrete construction. Certain types of steel fibres show considerably improved bond and anchorage in concrete compared to plain fibres, however, the different types of steel fibres are usually deformed only in two dimensions. Physical and chemical surface treatments may also be applied to enhance bond performance. Diameters and lengths of steel fibres vary from 0.1 to $1 \mathrm{~mm}$ and 10 to $60 \mathrm{~mm}$, respectively. There is, however, a gap in experience connected to the performance of steel fibres deformed in 3D.

Three types of bond are available in SFRC: 1) elastic force transfer; that is the adhesion of the fibres to the concrete, 2) frictional force transfer; that is provided by friction between the fibres and the concrete giving resistance against pull-out and 3) mechanical force transfer; that is provided by mechanical interlock of the fibres that are intentionally deformed along their lengths. Development of steel fibres which are deformed in $3 \mathrm{D}$ may provide better bond performance by enhancing frictional force transfer component and mechanical force transfer component of the bond action.

\section{Steel fibres with novel 3D geometry}

In the present research and development project (started in October, 2013), four different types of 3D deformed steel fibres and one type of 2D deformed steel fibre were designed, manufactured and studied under laboratory conditions [7]. The 2 dimensionally deformed fibre was the basic fibre that was used for the further 3 dimensional deformation process during manufacturing. A special device was constructed to produce the special fibres. The device was designed directly for the present research and development project and the prototype fibres were manufactured manually with the use of the device.

The basic 2 dimensionally deformed steel fibre received the product name of PetiX (Fig. 1). The basic 2 dimensionally deformed steel fibre has a waved shape with three waves. The magnitude of the waves is intentionally selected to be larger than that of the commercially available for the waved geometry steel fibres. The larger waves were chosen due to an expected better performance of the fibres when they are deformed in 3 dimensions. With smaller waves of the basic fibre the effect of the 3 dimensional deformations was expected to be less remarkable.

The first 3D fibre is the PetiX V45 type steel fibre (Fig. 2). This is the shape of $3 \mathrm{D}$ geometry that was developed first during the research and development project, and this is the type of fibre that was actually the initiation that started the research, back in October 2013. The identifying feature of the 3 dimensionally deformed PetiX V45 type steel fibre is the middle wave that is bent out from the basic fibre's 2D plane with 45 degrees.

The second type of the 3D fibres is the PetiX V90 type steel fibre (Fig. 3). This extremely deformed type of fibre was created since it was unknown how the extent of the deformation could influence the behaviour of the fibres in concrete. The concept is the same for the PetiX V90 type steel fibre as it was for the PetiX V45 type steel fibre, but the deformation rate was selected to be 90 degrees, rather than 45 degrees. 

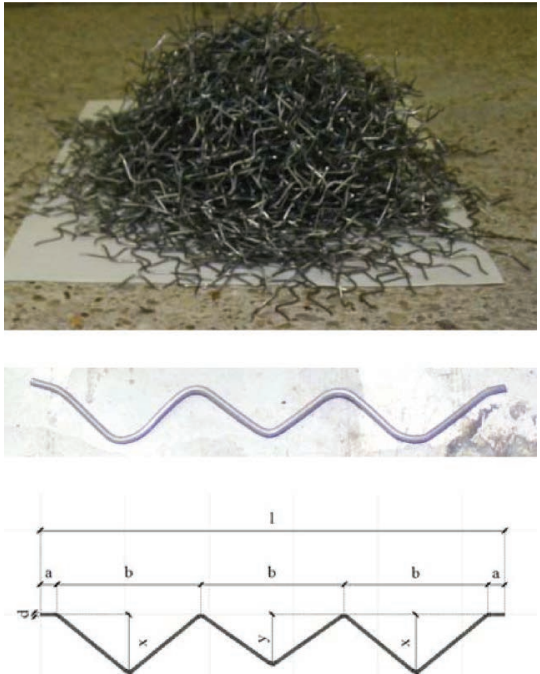

Fig. 1. $2 D$ deformed basic steel fibre, PetiX

1. ábra Két dimenzióban megmunkált PetiX alapszál
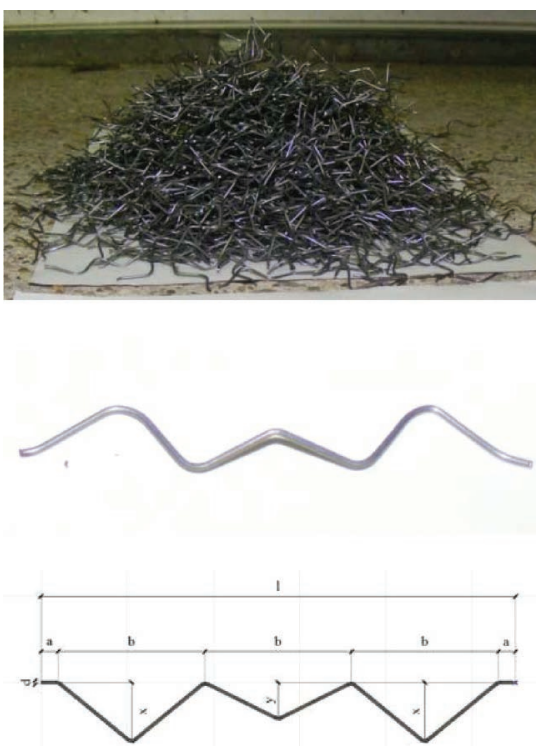

Fig. 2. 3D deformed steel fibre, PetiX V45

2. ábra Három dimenzióban megmunkált PetiX V45 acélszál
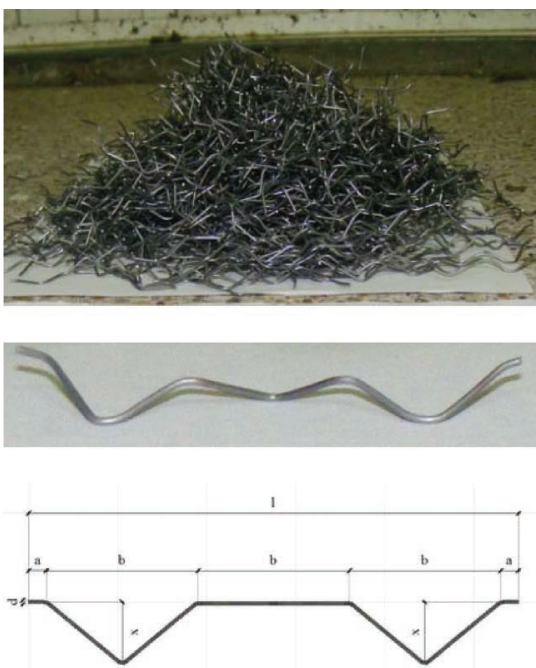

Fig. 3. 3D deformed steel fibre, PetiX V90

3. ábra Három dimenzióban megmunkált PetiX V90 acélszál
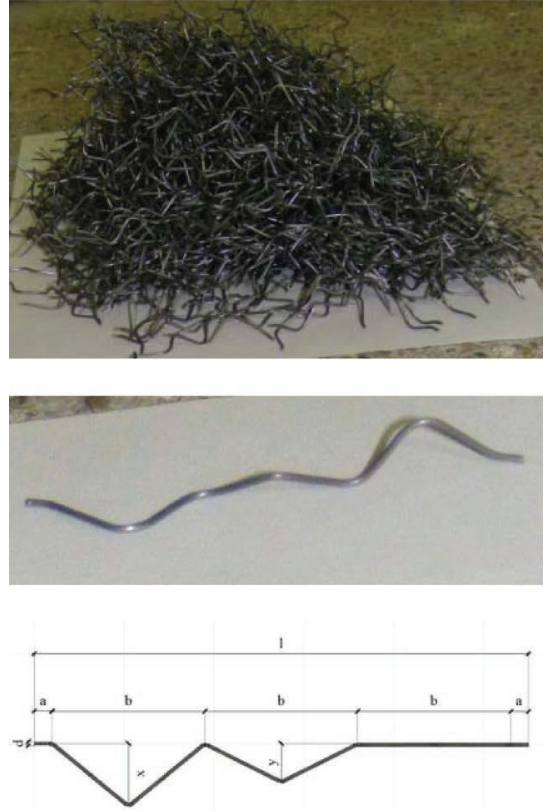

Fig. 4. 3D deformed, twisted steel fibre, PetiX S45

4. ábra Három dimenzióban megmunkált PetiX S45 acélszál
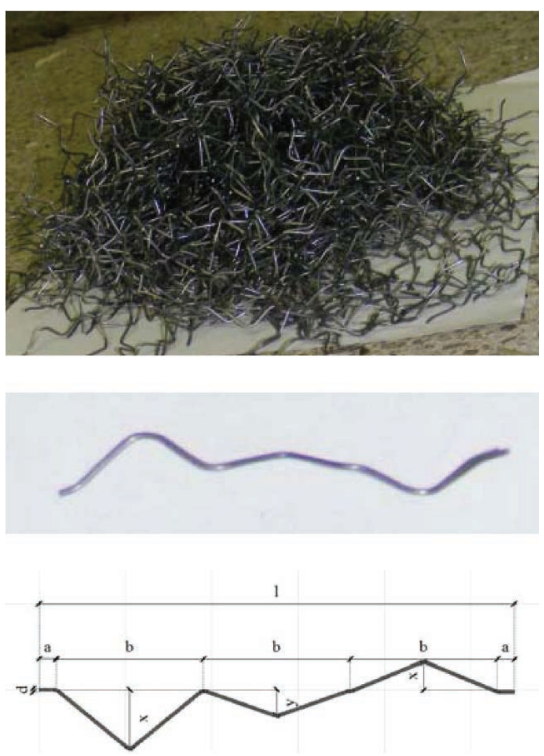

Fig. 5. 3D deformed, twisted steel fibre, PetiX S60

5. ábra Három dimenzióban megmunkált PetiX 560 acélszál

The third type of the 3D fibres is the PetiX S45 type steel fibre (Fig. 4). It provides a spiral-like appearance since the shape of geometry of the $2 \mathrm{D}$ basic PetiX fibre made it possible to create a spiral-like, twisted steel fibre as well during the 3D deformation process. Its attribution is that every wave is bent 45 degrees further out from plane than the previous wave.

The fourth type of the 3D fibres is the PetiX S60 type steel fibre (Fig. 5). The shape of geometry is very similar to that of the PetiX S45 type steel fibre, but at this type the extent of the deformation is 60 degrees, rather than 45 degrees.

Cold drawn steel wire raw materials were used for the present experimental program with a nominal tensile strength of 1400 $\mathrm{N} / \mathrm{mm}^{2}$, provided by D\&D Drótáru Zrt., Hungary. 


\section{Experiments}

Two different experimental test series were conducted with the novel type 3D geometry steel fibres. A series of three-point bending tests were carried out on prismatic SFRC specimens and a series of hinged beam pull-out tests were carried out on special design prismatic mortar specimens with cast-in hinges.

For the three-point bending tests $70 \times 70 \times 250 \mathrm{~mm}$ prismatic SFRC specimens with $30 \mathrm{~kg} / \mathrm{m}^{3}$ steel fibre dosage were used. Twelve individual specimens were prepared for each type of the novel type 3D geometry steel fibres to get reliable results. Specimens were tested at a span of $200 \mathrm{~mm}$ under one concentrated load at mid-span. Specimens were monotonically loaded with static loading up to complete flexural failure - that resulted the separation of the prismatic SFRC specimens to two blocks. Corresponding load and deflection values were continuously recorded and the load-deflection responses were prepared. Load-deflection responses were used for the comparative performance analysis.

For the hinged beam pull-out tests $40 \times 40 \times 160 \mathrm{~mm}$ mortar prisms were prepared. During specimen preparation, three individual fibres were placed at the middle sections of the prisms running through a polystyrene plate of $7 \mathrm{~mm}$ thickness. A steel hinge was placed over the middle section in each specimen as a load distributing element. Specimens were tested at a span of $100 \mathrm{~mm}$ under one concentrated load at mid-span, located on the steel hinge. Specimens were monotonically loaded with static loading up to complete bond failure - that resulted either the pull-out of the fibres from the to two blocks or the splitting of the cover over the steel fibres. Corresponding load and deflection values were continuously recorded and the load-deflection responses were prepared. The bond performance can be studied by the load-deflection responses since fibres can be considered to be loaded in pure tension due to the special loading conditions provided by the hinged beam pull-out tests.

\section{Results}

Present paper summarizes the experimental results of exclusively the $70 \times 70 \times 250 \mathrm{~mm}$ prismatic SFRC specimens tested in three-point bending. Load-deflection curves are indicated in Fig. 6. The curves indicated represent the average curves of the individual 12 load-deflection responses recorded for each type of steel fibres. As a reference, hooked-end steel fibres (product of D\&D, Hungary) were also tested. For the better visualization of the performance differences, Fig 6.b provides these averaged results with a vertical axis of relative load that gives the load values of the specimens prepared with the novel type steel fibres as ratios of load recorded for the reference specimens prepared with hooked-end fibres at the same deflection level. It can be clearly realized that the novel type steel fibres provide superior performance with increased flexural toughness. Due to the large waves of the 2 dimensionally deformed basic PetiX steel fibre, higher flexural resistance is available than that of the reference SFRC specimens prepared with hooked-end steel fibres. At $7.5 \mathrm{~mm}$ mid-span deflection the difference exceeds $30 \%$. Steel fibres that are deformed in $3 \mathrm{D}$ provide better performance than that of the 2 dimensionally deformed basic PetiX steel fibre. Certain fibre geometries (e.g. PetiX V45 and PetiX S60) can give 1.4-times higher flexural resistance than the reference SFRC specimens prepared with hooked-end steel fibres. It can be also realized that the performance of PetiX V90 is inferior with decreased flexural toughness. The behaviour is attributed to the middle wave of the fibre that is bent out from the basic fibre's 2D plane with 90 degrees. Such large deviation in geometry without gradual change results a more pronounced tendency of forming tangles of fibres during mixing and may result an uneven distribution of fibres within the concrete matrix, additionally to the fact that the fibres themselves are more sensitive to rupturing within concrete cracks due to the large local deformations by their extreme shape.
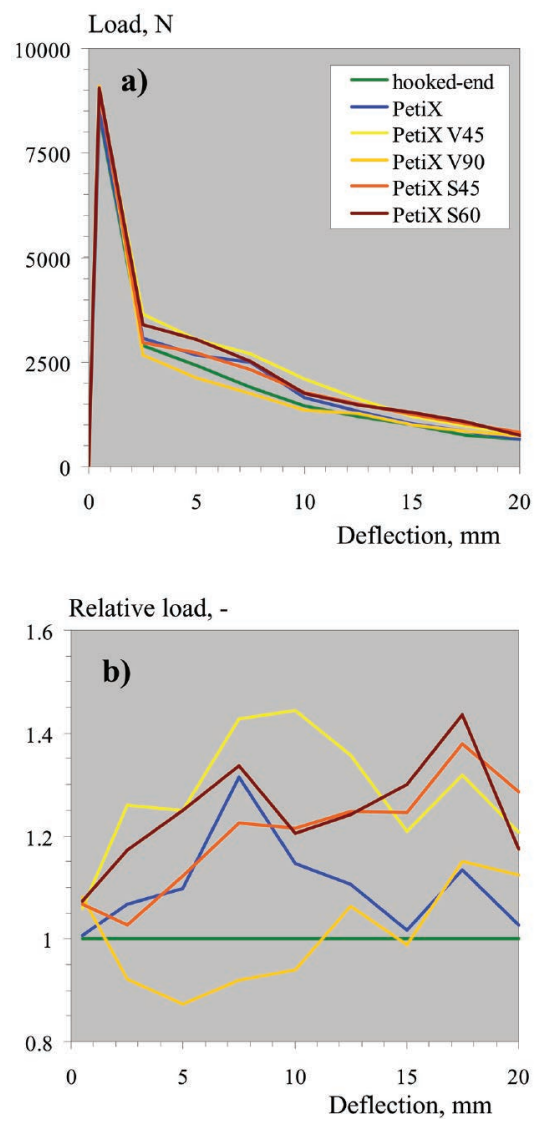

Fig. 6. Load-deflection responses of SFRC specimens

6. ábra SFRC hasábok terhelöerö-lehajlás diagramjai

If one defines flexural toughness as the area under the load-deflection response then the performance of the fibres can be compared by this integral type of material parameter as a general indicator, being independent of the values of deflection. Relative flexural toughness values are indicated in Fig. 7 (taking 100\% for the flexural toughness of reference SFRC specimens prepared with hooked-end steel fibres). The superior performance of both $2 \mathrm{D}$ and $3 \mathrm{D}$ PetiX steel fibres is clearly visible together with the inferior performance of PetiX V90. Highest flexural toughness was reached by PetiX V45 and PetiX S60 type 3D deformed steel fibres. 
Relative toughness index,

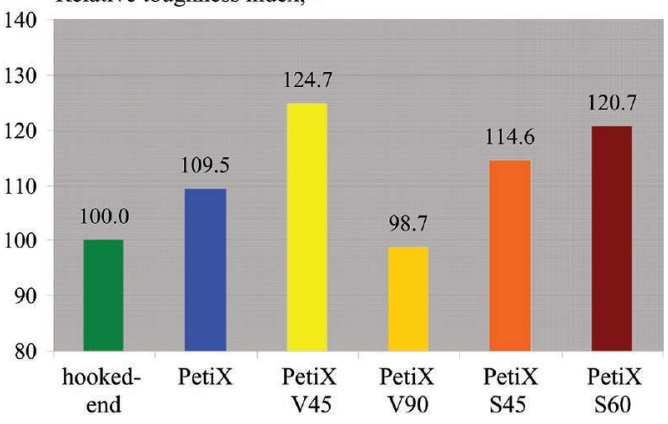

Fig. 7. Relative toughness indices of SFRC specimens

7. ábra SFRC hasábok relatív szívóssági indexei

Another suitable indicator for the enhanced bond and corresponding increased toughness of the 3D deformed steel fibres can be the ratio of the number of the ruptured and pulled-out fibres within the cross sections of cracks resulting flexural failure of the prismatic specimens. After the failure of the specimens, the resulting two blocks of the prisms were separated from each other and the failure mode of each individual steel fibre in the crack sections was carefully observed and recorded. Fig. 8 summarizes the results. The bar chart indicates the ratio of the number of the ruptured fibres to the total number of fibres within the cross sections of cracks (summarized for all the 12 individual prismatic specimens), given in percents. For the reference SFRC specimens prepared with hooked-end steel fibres no fibre rupture was observed. All fibres were pulled-out from the concrete matrix at the cross sections of cracks. Best performance was observed for PetiX V45 and PetiX S45 type 3D deformed steel fibres. It should be highlighted here as well that the results for PetiX V90 type 3D deformed steel fibres is misleading in this representation. One should observe that the smallest number of fibres was found in the failure cross sections for V90 type 3D deformed steel fibres due to the uneven distribution of fibres and the extreme deformation of this type of fibre geometry resulted the high ratio of ruptured fibres observed and the reason is not the enhanced bond capacity of the fibres.

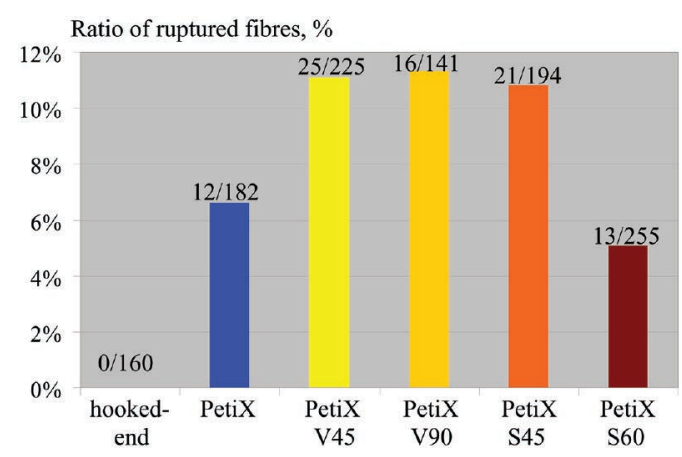

Fig. 8. Ratio of ruptured fibres in SFRC specimens

8. ábra Elszakadt acélszálak aránya SFRC hasábokban

\section{Conclusions}

The present research and development project designed, manufactured and tested one novel type of 2D deformed steel fibre (receiving the product name of PetiX) and four different types of 3D deformed steel fibres (PetiX V45; PetiX V90; PetiX S45; PetiX S60) under laboratory conditions. It was demonstrated that certain types of 3D deformed steel fibres can hold considerably improved the bond performance in concrete that results increased flexural toughness of SFRC prismatic specimens tested in flexure.

\section{Acknowledgements}

Authors gratefully acknowledge the support of the Hungarian Scientific Research Fund project "Durability and performance characteristics of concretes with novel type supplementary materials" (OTKA K 109233). Special thanks to D\&D Drótáru Zrt., Hungary for providing cold drawn wire raw materials and hooked-end steel fibres.

\section{References}

[1] Balaguru, P. N. - Shah, S.P. (1992): Fiber-reinforced cement composites. McGraw-Hill, New York, 1992, 530 p.

[2] Bentur, A. - Mindess, S. (2007): Fibre-reinforced cementitious composites. 2nd ed. Taylor \& Francis, New York, 2007, 660 p.

[3] Brandt, A.M. (2008): Fibre-Reinforced Cement-based (FRC) composites after over 40 years of development in building and civil engineering. Composite Structures, Vol. 86, No. 1-3, pp. 3-9. http://dx.doi.org/10.1016/j. compstruct.2008.03.006

[4] Banthia, N. - Bindiganavile, V. - Jones, J. - Novak, J. (2012): Fibrereinforced concrete in precast concrete applications: research leads to innovative products. PCI Journal, Vol. 57, No. 3, pp. 33-46.

[5] Walraven, J.(2009): High performance fiber reinforced concrete: progress in knowledge and design codes. Materials and Structures, Vol. 42, pp.1247-1260. http://dx.doi.org/10.1617/s11527-009-9538-3

[6] di Prisco, M. - Plizzari, G. - Vandewalle, L. (2009): Fibre reinforced concrete: new design perspectives. Materials and Structures, Vol. 42, No. 9, pp. 1261-1281. http://dx.doi.org/10.1617/s11527-009-9529-4

[7] Kerekes, P. (2014): 2 and 3 dimensional steel fibers with novel geometry: design, development and comparison of effectiveness in concrete (supervisor: Borosnyói, A.), Budapest University of Technology and Economics (BME), Faculty of Civil Engineering, Thesis submitted for the Students' Scientific Workshop 2014, 50 p. (in Hungarian)

Ref::

Kerekes, Péter - Borosnyói, Adorján: Performance of novel type three dimensionally deformed steel fibres for concrete Építöanyag - Journal of Silicate Based and Composite Materials, Vol. 66, No. 4 (2014), 105-108. p. http://dx.doi.org/10.14382/epitoanyag-jsbcm.2014.19

Új típusú, három dimenzióban megmunkált acélszálak tulajdonságai

Egy két éves kutatás-fejlesztési projekt elsố eredményeit mutatja be a cikk. A kutatás során egy fajta, 2 dimenzióban megmunkált acélszál (PetiX), és négy fajta, 3 dimenzióban megmunkált acélszál (PetiX V45; PetiX V90; PetiX S45; PetiX S60) lett kifejlesztve. A laboratóriumi vizsgálatok eredményei kedvezőek. Bizonyításra került, hogy egyes 3 dimenziós geometriai kialakításokkal jelentôs mértékben növelhetô az acélszálak tapadása betonban, és ezzel fokozható a szélerôsítésú betonok hajlítási szívóssága, amelyet a laboratóriumi vizsgálatok eredményei igazolnak.

Kulcsszavak: beton, acélszál, 3 dimenziós geometria, tapadás, hajlítószilárdság, szívósság 